\title{
Constructing Women's Language and Shifting Gender Identity through Intralingual Translanguaging
}

\author{
Eriko Sato \\ Stony Brook University (State University of New York), USA
}

\begin{abstract}
Japanese has many language varieties based on users' social attributes such as gender, age and occupation. Regardless of whether each variety represents how people actually speak, each of them has a specific set of linguistic features and a socio-psychological group identity of its users. This paper analyzes women's language (onna kotoba) and the use of gender-sensitive first-person pronouns (e.g., (w)atashi, boku, ore, jibun) in Japanese based on the perspective of translanguaging and a multifaceted model of the theory of identity. It shows that women's language in Japanese was constructed by deploying some of the linguistic features of multiple language varieties that have developed in different contexts while being shaped by maledominant ideology during Japan's modernization process. It also shows how gender-sensitive linguistic boundaries are manipulated moment by moment by language users, affecting their master, interactional, personal, and/or relational identities.
\end{abstract}

Index Terms — translanguaging, identity, gender, language variety, Japanese, sociolinguistics, pronouns

\section{INTRODUCTION}

Japanese has many language varieties based on users' social attributes such as gender, age and occupation. Regardless of whether each variety represents how people actually speak, each of them has a specific set of linguistic features and a socio-psychological group identity of its users. The question is how these language varieties evolve, how their group identities are constructed, and when the boundaries between language varieties are manipulated and why. This paper analyzes women's language (onna kotoba) and gender-sensitive first-person pronouns (e.g., (w)atashi, boku, ore, jibun) in Japanese based on the perspective of translanguaging (García and Li, 2014; $\mathrm{Li}, 2011,2016,2018$ ) and a four-way model of the theory of identity (Tracy, 2002; Young, 2017).

Although precise definitions vary depending on the scholar's focus, translanguaging is generally assumed as the use of linguistic features disregarding the boundaries between named languages. ${ }^{1}$ However, there is no reason why the boundaries that translanguaging is sensitive to have to be those between named languages. The naming of languages is a relatively recent phenomenon $(\mathrm{Li}, 2018, \mathrm{p} .19)$, and thus the majority of languages are unnamed languages or language varieties. Furthermore, as Otheguy, García, \& Reid (2015) argue, what we speak are all unique idiolects. Li (2018) redefines translanguaging, with more precision, as the use of "one's idiolect" disregarding "socially and politically defined language names and labels," through which we think "beyond the boundaries of named languages and language varieties including the geography-, social class-, age-, or gender-based varieties," while being fully aware of such boundaries (p. 19). ${ }^{2}$ One of the most important theoretical contributions of translanguaging conceptualized in García \& $\mathrm{Li}(2014)$ and $\operatorname{Li}(2011,2016,2018)$ is to reveal the socio-interactional nature of language and to explain how languages evolve through multimodal and multisensory translanguaging instinct.

Language varieties are closely related to their users' group identities. However, how to understand identity is an epistemological question and different researchers have different ways of understanding identities. In particular, how bilinguals conceive, negotiate and construct their identity and how their language use affects their identity are complex questions. Young (2017) presents an in-depth examination of prominent theories of identity in relation to language and argues that a simple theory where one's identity equals his/her native language (Fishman, 1991) fails to describe the complex and dynamic identity of multilinguals (Pavlenko \& Blackledge, 2004; Myhill, 1999; Bucholz \& Hall, 2004). He hence evaluates theories of identity adopting the multifaceted model of identity proposed by Tracy (2002) and shows how bilinguals' local identities are influenced by hegemonic languages but are also negotiated through creative and strategic language use, drawing concepts of "languaging" (Chow, 2014) and "polylanguaging" (Jørgensen, Karrebæk, Madsen, \& Møller, 2011). Young's (2017) approach towards the identity of bilinguals does not have to be limited to the speakers of multiple named languages given that named languages are nation-state inventions. It can also

\footnotetext{
${ }^{1}$ See García and Li (2014), Li (2011, 2016, 2018), García (2007, 2009), Otheguy, García and Reid (2015), Garcia and Lin (2016, 2018), Lee (2015), Lin (2014), Baker (2001, 2003), Canagarajah (2011), Blackledge and Creese (2010), Creese and Blackledge (2010), Makoni and Pennycook (2007), Lewis, Jones, \& Baker (2012), Sato (2017, 2018a, 2018b), Sato \& Sharma (2017) among others for the proposals and applications of translanguaging.

${ }^{2}$ See Sato (2018a, 2018b) for the analysis of intralingual translanguaging between vocabulary classes, Sino-Japanese and native Japanese.
} 
be applied to the speakers of a language variety. Therefore, I will apply Tracy's multifaceted model of identity to the analysis of the group identity of the users of women's language in Japanese.

Tracy (2002) argues that postmodernists see identity as fragmented, contradictory, competing, and in flux: identities are stable and pre-existing features, and are also dynamic and situated; identities are social categories and are also personal and unique (p. 17). Accordingly, Tracy (2002) proposes four kinds of identities: master, interactional, personal and relational. This is shown in Fig. 1 below:

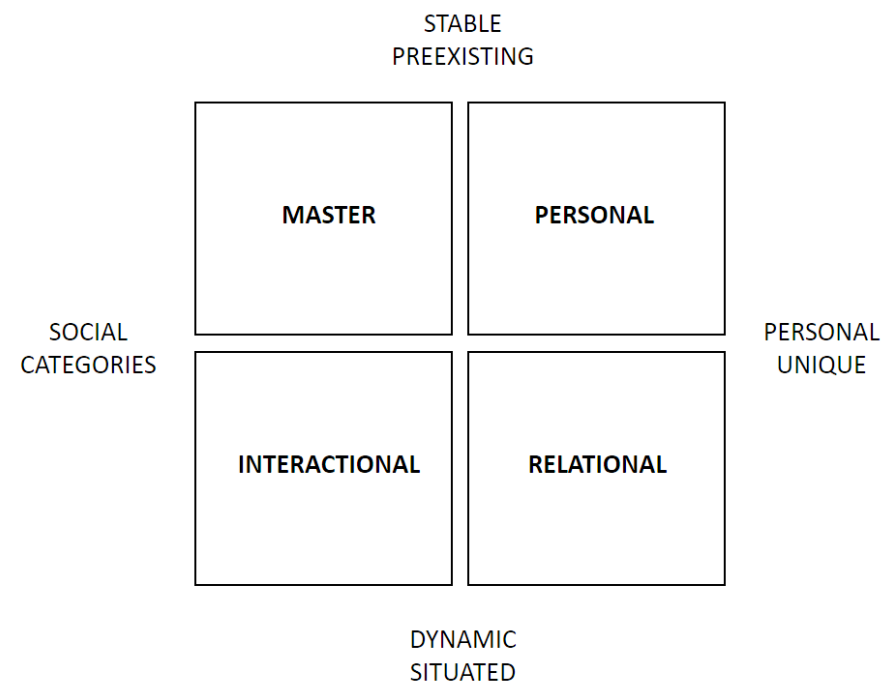

Figure 1. Conceptualizing identities (Source: Tracy, 2002, p. 20)

Master identities refer to a social category one belongs to based on his/her gender, age, race, ethnicity, national and regional origins, etc. Interactional identities refer to one's specific roles in society such as a teacher, a mother, a wife, a customer, etc. Personal identities refer to one's unique personalities such as being honest, hotheaded, gossiper, etc. Finally, relational identities refer to the kind of relationship one holds with a particular conversational partner in a specific situation (Tracy, 2002, pp. 18-19).

Based on the four-way model of identity proposed by Tracy (2002), this paper explores the roles of translanguaging (Garcia \& Li, 2014; Li, 2011, 2016, 2018) for shaping a language variety and its users' identity by analyzing the data from some of the preceding studies through a translanguaging perspective. Section II provides a socio-historical analysis of women's language in Japanese, where translanguaging plays an important role for deploying linguistic features from different language varieties to form a new language variety, closely reflecting the rapidly modernizing Japanese society during the Meiji period (1868-1912). Section III provides a socio-interactional analysis of gendersensitive personal pronouns in Japanese, where gender-based boundaries are strategically manipulated through translanguaging by fictional characters, junior high school students, and employees of lesbian bars. Section IV provides conclusions and implications.

\section{WOMEN'S LANGUAGE IN JAPANESE}

Japanese is well-known for its distinct gendered language called onna kotoba, josei-go, or fujin-go, all of which literally mean “women's language” (Inoue, 2002, 2006; Endo, 1997, 2008, M. Nakamura, 2008, 2014; Okamoto \& Smith, 2008; Okamoto \& Shibamoto-Smith, 2016; Ide \& Terada, 1998). For example, it is easy to see that ara, neko da $w a$ is a woman's utterance whereas are, neko da zo is a man's utterance although both of them mean "Oh, it's a cat." This is because the interjection, ara "oh," and the sentence ending, $d a w a$ (the copula plus a sentence final particle) are characteristic features of women's speech. Okamoto and Smith (2008) provide a collection of scholarly characterizations of women's language. Frequently noted general stylistic features of women's language are polite, gentle/soft, refined/elegant, verbose, indirect, unassertive, imprecise, emotional, and empathetic (Okamoto \& Smith, 2008, p. 92). They also list frequently noted specific linguistic features (Okamoto and Smith, 2008, p. 92):

- first/second-person pronouns (e.g., atashi, anata)

- $\quad$ sentence final particles (e.g., wa, kashira)

- honorifics (e.g., o-Verb-ni naru)

- beautification prefix $o$ -

- high voice pitch, large pitch range, rising intonation at sentence end

- avoidance of particular phonological reductions (e.g., umē for umai "delicious")

- interjections (e.g., ara "oh", $m \bar{a}$ “"oh")

- avoidance of "vulgar" expressions (e.g., kū "eat," chikushō "damn”)

- avoidance of Sino-Japanese words 
- $\quad$ indirect directive forms (e.g., Verb-te)

- incomplete sentences

The history of women's language is not very long. Endo (1997) argues that gender-based linguistic differences cannot be identified in earliest texts created in Japan. For example, The Kojiki (Records of Ancient Matters), the oldest extant chronicle in Japan completed in 712, presents a scene where a male deity (Izanagi) and a female deity (Izanami) agree to have conjugal intercourse, and then Izanami first says to Izanagi, "ana-ni-ya-shi e wotoko-wo (how good a lad!)," which was followed by Izanagi's saying to her, "Ana-ni-yashi e wotome-wo (how good a maiden!)." ${ }^{3}$ Their utterances differ only in terms of the words, wotoko (lad) and wotome (maiden) just to refer to each other, and there is no other difference at all, suggesting the absence of gendered language when The Kojiki was written (Endo, 1997, p.4). ${ }^{4}$ Endo (1997) also examines The Man'yōshü (Collection of Ten Thousand Leaves), the oldest extant anthology of poetry in Japan, compiled in the latter half of the 8th century. The Man'yōshū contains 4,516 poems in 20 books, mostly written from the second quarter of the 7th century to the middle of the 8th century. Its content varies from the elegant banquet verse of aristocrats to the poems of the frontier guardsmen and the rustic poems of the Eastland (I. H. Levy, 1981, p. 3). 106 out of 530 authors who contributed to this collection were women and its editors also included women, but no work in it shows gender-based linguistic differences, suggesting the absence of gendered languages in the Nara period (710-794) (Endo, 1997, pp. 3-13). Literary texts in the Heian period (794-1185) such as Makura no Sōshi (The Pillow Book, 1002) written by Sei Shōnagon (ca. 966-1025) and Genji Monogatari (The Tales of Genji, ca. 1021) written by Murasaki Shikibu (ca. 973-1031) show no specific gender-based linguistic characteristics, although the content of these texts depict gender-based societal differences: Women were excluded from acquiring Chinese literacy, allowed to write only in hiragana (cursive syllabary), ${ }^{5}$ and discouraged to use kango (Sino-Japanese compound words) (Endo, 1997, p. 23).

What is the origin of the linguistic features that characterize women's language that we recognize today in Japanese? There are two major theories for this: teyo-dawa language (schoolgirls' language) and court ladies' language. Inoue (2002) argues that women's language has emerged from so-called teyo-dawa language (teyo-dawa kotoba) in the late 19th and early 20th centuries. Teyo-dawa language is also called schoolgirls' language (jogakusei kotoba) because it was predominantly used by secondary school female students, and is characterized by sentence endings such as te yo, da wa, no yo, and koto as in yoroshikute yo (it is fine), suteki da wa (it is wonderful), oishii no yo (it is delicious) and kamaimasen koto yo (it is not a problem). By "schoolgirls" Inoue (2002) refers to "the daughters of elite families, who could afford to go to secondary schools, the highest education for girls in the Meiji period (1868-1912), which were founded after the Meiji Restoration"; they represented a new social category of female, which was "neither producers (workers) nor reproducers (mothers)" (p. 406). They constituted only less than $0.09 \%$ of the female school-age population in Japan in 1890, and only $0.38 \%$ in 1900 (Inoue, 2006, p. 38). Inoue (2002) argues that the reason why a speech style of such a small population grew to be women's language is due to genbun itchi (speech and writing unification). Genbun itchi played an important role in forming the modern literary genre shōsetsu (novels), a narrative prose style, in the Meiji period. Because of genbun itchi, these novels frequently showed women's utterances as a part of reported speech and circulated them through mass print in a form of newspaper and magazines, targeting the middle class (Inoue, 2002, p. 396-397). As their speech style was cited and printed repeatedly in novels, books and newspapers, an image of a new type of woman and her speech style in the rapidly modernizing country was quickly created. According to Inoue (2002), teyo-dawa language was initially perceived as strange and unpleasant by male intellectuals and educators. Some claimed that this speech was originally "part of the vulgar speech used by daughters of low-rank samurai families" and others claimed that these endings were used by those in "pleasure quarters and teahouses" (Inoue, 2002, p. 406). Bohn \& Matsumoto (2008) state that in addition to using such teyo-dawa endings, which was viewed as "coarse and unladylike," schoolgirls were "using Sino-Japanese compounds, fewer honorific expressions, and borrowings from English and other foreign languages, i.e., expressions that were normally associated with male students rather than with idealized women" (p. 52). Bohn \& Matsumoto show some interesting excerpts of women's reported speech from novels:

(1) Kuikki mōshon na hito nē.

"She is quick, isn't she?"

(Miyake, 1957[1888], p. 42, cited in Bohn \& Matsumoto, 2008, p. 60)

(2) Oya ano kata wa $\mathrm{H}$ (etchi) janai no?

"Oh dear, isn't that person her fiancé?"

(Miyake, 1957[1888], p. 43, cited in Bohn \& Matsumoto, 2008, p. 60)

(3) Kitto anata o enbiru mono no shita koto nan da wa.

"Certainly, someone who was envious of you must have done it."

(Kosugi, 1930[1903], p. 47, cited in Bohn \& Matsumoto, 2008, p. 60)

\footnotetext{
${ }^{3}$ The English translations are from Philippi (1969, p. 51).

${ }^{4}$ It is also interesting that after each of the deities had finished speaking, Izanagi said to Izanami that it was not proper that the woman spoke first. Although Endo (1997) interprets it as a sign of male dominance in Japan (p. 4), Philippi (1969) considers that it was influenced by Chinese ideas and doubts that the ancient Japanese had any clear-cut idea of male supremacy (p. 52).

${ }^{5}$ See Sato (2018a, p. 319) for the analysis of Ki no Tsurayuki's use of hiragana in writing The Tosa Nikki (The Tosa Diary, 935) from translanguaging perspective.
} 
The utterance in (1) was made by a female student describing another female student who quickly picked up a piece of cake and ran down the hallway while eating it. The utterance in (2) was made by a female student who was gossiping about the misbehavior of the daughter of a viscount. $H$ is an abbreviation for husband used as jargon among female students at the time the novel was written. It actually referred to one's fiancé. Enbiru in (3) was created from enbi (transliteration of "envy"). The above three examples can be seen as the outcomes of translanguaging, but they also involve some word formation. The seemingly noun phrase, kuikki mōshon "quick motion," in (1), is not used as a noun phrase in this sentence, but as the stem of a nominal adjective, and thus it is followed by the suffix $n a$ to create a nominal adjective. $H$ in (2) is the outcome of abbreviation, the initial letter of husband. Enbiru in (3) is the outcome of shortening the transliteration of the verb envy (enbī $\rightarrow$ enbi) and adding a Japanese verbal suffix $r u$ as in $e n b i-r u$.

On the other hand, Endo $(1997,2008)$ argues that what is today called onna kotoba or josei-go originated from court ladies' language (nyōbo kotoba), a speech style that emerged in the 14th century as a women's form of speech within the closed world of the imperial court. After the formation of warrior society in the 13th century, women's social standing declined and more honorific forms started to be used by women toward men (Endo, 1997, pp. 50-51). According to Endo (1997) court ladies' language is characterized by the following linguistic features (pp. 56-59):

- Use of the honorific/beautification prefix $o$ - (e.g., sakana "fish" $\rightarrow o$-sakana)

- Abbreviation (e.g., takenoko "bamboo shoot" $\rightarrow$ take)

- Addition of the suffix -moji to a part of a word (e.g., sushi "sushi" $\rightarrow$ su-moji)

- Addition of the abstract noun mono "thing" to a notion associate with the referent (e.g., nabe "pot" $\rightarrow$ kuromono "black thing" to mean "pot")

- Word-formation based on color, shape and associated meaning of the referent (e.g., iwashi "sardine" $\rightarrow$ murasaki "purple" to mean "sardine")

- Reduplication (e.g., surume "dried cuttlefish" $\rightarrow$ surusuru)

- Avoidance of Sino-Japanese words (kango) (e.g., kaji "fire (conflagration)" $\rightarrow$ akagoto "red incident" to mean "fire (conflagration)")

Court ladies' language sounded polite due to the frequent use of the honorific/beautification prefix $o$-, noble because of vagueness (e.g., use of the abstract noun mono (thing) for referring to varied items along with their partial meanings), elegant because of its unassertiveness (e.g., avoidance of Sino-Japanese compound words), and pleasing to the ear because of the avoidance of Sino-Japanese words that are filled with strong sounds such as voiced obstruents, palatalized or labial sounds (Endo, 1997, p. 59; Endo, 2008, p. 14). On the other hand, court ladies' language sounded childish due to reduplication, abbreviation and clipping. In the Edo period (1603-1867), court ladies' language further expanded its vocabulary for elite women, being joined by another newly emerged variation called "serving-women's language" (jochü kotoba) or the language of the women of the court and the Shogun's residence (Endo, 2008, p. 16). Then, it was adopted by "court nobles, the warrior society, and affluent townspeople, as a model of superior women's language" (Endo, 2008, p. 15). Court ladies' language was assigned to serve as the ideal model of women's speech in pre-modern times due to its gentleness, elegance and feminineness, and it "ultimately led to attempts to impose on all women a normative way of speaking in modern Japan" (Endo, 2008, p. 10).

So far, we have seen two possible origins of women's language in Japanese: schoolgirls' language and court ladies' language. Recall the features of women's language listed by Okamoto and Smith (2008), which we discussed earlier in this section. We notice that some features exist in schoolgirls' language, and some other features exist in court ladies' language: sentence final particles such as $w a$ is a part of teyo-dawa language (schoolgirls' language); beautification prefix $o_{-}$, avoidance of Sino-Japanese compounds, vagueness and indirectness are part of court ladies' language. This shows that women's language in Japanese was formed through translanguaging schoolgirls' language and court ladies' language. ${ }^{6}$ The contradictory area is the use of non-native Japanese vocabulary as pointed out by Bohn \& Matsumoto (2008): Schoolgirls' language is characterized by the frequent use of Sino-Japanese and English (neo-)borrowings, whereas court ladies' language is not. However, the use of non-native Japanese vocabulary might have been situationbound rather than being a contradictory feature between schoolgirl's language and court ladies' language: as Tracy (2002) assumes, the identity is multifaceted and includes relational identity, which changes depending on who one communicates and interacts. In addition, the use of non-native Japanese must have gradually increased among all Japanese speakers as more Western concepts were introduced to Japan during its modernization period. The analysis of women's language in Japanese as the outcome of translanguaging schoolgirls' language and court ladies' language is also supported by Inoue's (2002) observation that linguistic characteristics of schoolgirls' language were combined with elaborate honorifics to construct the voice of new middle- and upper-class women in novels:

By the early 20th century, final particles such as teyo, dawa, noyo, and others, which were once viewed as vulgar, had thus come to be increasingly attributed to new middle- and upper-class women in the novels. In combination with elaborate honorifics, these final particles were thus

\footnotetext{
${ }^{6}$ Ide and Terada (1998) argue that courtesans' language (yüjo kotoba) that emerged in the 17th century contributed to the origin of women's language in addition to court ladies' language. It is possible that the reason why this speech style spread to middle and upper class in the Meiji period is because the strict social stratification enforced in the Edo period was officially deconstructed in the Meiji period, and marriage between different social classes became possible as we can see some geisha who got married to upper-class men in the Meiji period (C. Nakamura, 2018). This is a very promising research area, but is beyond the scope of the current study, where the focus is the application of translanguaging perspective to the analysis of the development of women's language.
} 
instituted as the voice of those who were depicted as haikara (lit., "high-collar," meaning modern, Western, and stylish).

(Inoue, 2002, p. 408)

The Meiji period was a dramatic turning point for Japan for many reasons. Japan was in the transition from premodern to modern, from closed to open, from stratified society to democratic society, from feudalism to capitalism, and more. Japan also needed to make education available to women to "establish a certain kind of equivalency between Japanese women and their female counterparts in the advanced nations of Europe" (I. Levy, 2006, p. 54). However, modernizing women was both beneficial and harmful for the male-dominant nation at the time. Women became vital promoters and consumers of modern culture, new fashion (e.g. hakama, long culottes customarily worn by men), new hairstyles, new literary genres, art and mass media, and schoolgirls became an icon of modern womanhood and modern society. These were beneficial to the nation because they could make the nation appear culturally advanced and positively stimulate the country's economy. On the other hand, the nation's priority at the time was fukoku-kyōhei (rich country and strong army), and thus the purpose of educating women in Japan was not to make them as intellectual, independent and assertive as men, but to strengthen them to effectively serve as ryōsai-kenbo (good wives and wise mothers) in the modernized era and to maintain their status as subordinate to men (Inoue, 2002, p. 397; Endo, 1997, p. 109; Okamoto and Shibamoto-Smith, 2016, p. 205). The fact that the Japanese society in the Meiji period had dual values as described above is consistent with the theory that women's language in Japanese was formed through translanguaging two language varieties in this period, reflecting on the social reality during the modernization period in Japan. The fundamental concept that underlies translanguaging is "languaging," a dynamic and continuous action that transforms the norms of language use, closely reflecting on the context of language use (García \& Li, 2014). When Japan was in the middle of modernization, traditional and modern values were coexisting, and a new language variety was formed through the deployment of linguistic features of both language varieties through translanguaging.

As the construction of a language variety is necessarily accompanied by the construction of its users' group identity, it follows that the group identity of the users of women's language in Japanese has inherited the group identities of the users of schoolgirls' language and the users of court ladies' language. As discussed earlier, identities are composed of master, interactional, personal, and relational identities (Tracy, 2002). Thus, each dimension of the group identity of the users of women's language in Japanese was formed by bringing the group identities of the users of schoolgirls and the users of court ladies together. To illustrate this line of analysis, let us map the identities of the users of these language varieties that were discussed earlier in this section to the four sub-identities in Tracy's (2002) model. First, master identity represents a stable and socio-categorical identity such as age and gender. Schoolgirls were young females, whereas court ladies were both young and old females. Thus, collectively, the master group identity of the speakers of women's language is predicted to be female, young and old. Second, the interactional identity represents one's roles in a society such as a teacher and a mother. Schoolgirls are "neither producers (workers) nor reproducers (mothers)" (Inoue, 2002, p. 406), but they are daughters and students. Court ladies are mothers, wives, and servants. Thus, collectively, the interactional group identity of the users of women's language is predicted to be daughters, wives, mothers, students, and servants. Third, personal identity represents one's unique personal characters. Schoolgirls are modern, open, playful, and assertive, as we can see from their creative translanguaging practices using linguistic features of English (modern, open, and playful) and from their frequent use of Sino-Japanese vocabulary (assertive). On the other hand, court ladies are traditional, polite, elegant, noble, soft, and unassertive, as we can see from their extensive use of honorifics (polite) and beautification prefix $o$ - (elegant), vagueness due to abbreviation and abstraction (noble), avoidance of SinoJapanese words (unassertive and soft), and the lack of linguistic elements from the West (traditional). Accordingly, the personal group identity of the speakers of women's language is dual in nature, and it varies depending on the communicative contexts: they may be modern, open, playful and assertive when talking with their female classmates at school, but traditional, polite, elegant, noble, soft, and unassertive when talking with their fathers, for example. Finally, the relational identity constructed by court ladies is subordinate to men, including their fathers and husbands, and later, their elder sons, as discussed earlier. On the other hand, schoolgirls are not subordinate to men as long as they are in school although they need to be subordinate to their fathers when they are at home. These collective facts and predictions are summarized in Fig. 2, where SG represents the group identities contributed by schoolgirls and CL represents the group identities contributed by court ladies: 


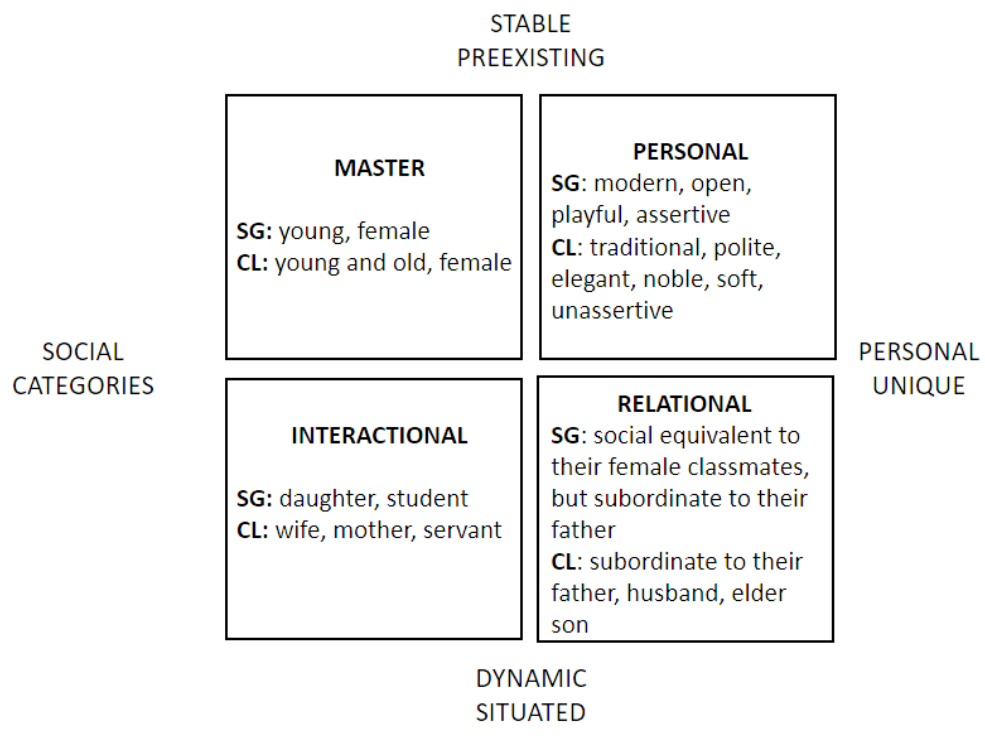

SG: users of schoolgirls' language

CL: users of court ladies' language

Figure 2. Identities of the users of women's language in the Meiji period

The collection of representative identities seems to adequately cover the overall group identity of upper- and middleclass women in the Meiji period, who may be playful and assertive when interacting with their female classmates at schools but may be mostly polite and unassertive when interacting with men. They are also consistent with the linguistic features of women's language in Japanese as well as schoolgirls' language and court ladies' language as we discussed earlier based on the information and data presented by Inoue (2002, 2006), Endo (1997, 2008), Okamoto \& Smith (2008), Okamoto \& Shibamoto-Smith (2016), and Bohn \& Matsumoto (2008). Most importantly, the theory of women's language as deriving from schoolgirls' language and the theory of women's language as deriving from court ladies' language are not in contradiction in Figure 2, but they complement each other and jointly capture the collection of linguistic features that support multifaceted identity of the users of women's language and the complex sociohistorical environment that fostered it during Japan's rapid modernization process.

\section{USE OF GENDER-SENSITIVE PERSONAL PRONOUNS}

The previous section presented how translanguaging facilitates the construction of a unique gender-based language variety by deploying multiple linguistic features from different language varieties, closely reflecting on the surrounding dynamic socio-historical contexts. This section presents how translanguaging facilitates the manipulation of a genderbased boundary by using gender-sensitive personal pronouns in Japanese, closely reflecting on the surrounding sociointeractional contexts.

The use of personal pronouns is gender sensitive in many languages. In Japanese the first-person pronouns for males include boku, ore and washi; those for females include atashi and atai. Watashi and watakushi are dominantly used by females, but are also used by males especially in formal contexts. Jibun is a gender-neutral reflexive pronoun that means "oneself," but is commonly used as a first-person masculine pronoun. However, Nishida (2011) discusses interesting fictional characters, boku-girl" (boku-shoujo), a girl character who addresses herself with boku, a first-person masculine pronoun, and ore-girl (orekko), a girl character, who addresses herself with ore, a blunt version of boku, as a part of his study of "role languages" (yakuwari-go) pioneered by Kinsui (2003). Role languages are language varieties assigned to certain types of fictional characters in anime, comic books, games and light novels, and each of them has a distinct set of linguistic features such as sentence final particles, choice of personal pronouns, pronunciation, intonation and vocabulary. ${ }^{7}$ According to Nishida (2011), boku-girls do not use stereotypical female speech styles. Instead, their speech is quite gender-neutral except for the use of boku, and they do not give any violent impressions. On the other hand, ore-girls speak vulgarly, and are often self-centered and aggressive (Nishida, 2011). This shows that a unique speech style and its associated group identity can be constructed by manipulating the gender-based linguistic boundaries. Producers of anime, games, and even foreign films with Japanese dubbings are extremely sensitive to subtle differences in characters' behaviors, appearances (e.g., hairstyle, clothing, body size), personalities, and biographic background,

\footnotetext{
${ }^{7}$ Kinsui (2014) lists over 50 role languages including realistic language varieties such as onna kotoba (women's language), wakamono kotoba (young people's language), and yakuza-go (gangsters' language), as well as language varieties for unrealistic characters such as kami-sama kotoba (gods' language), yūrei kotoba (ghosts' language) and uchüjin-go (space aliens' language).
} 
and they instruct their voice talents to deploy specific linguistic elements to form a unique speech style for each character. If a specific style is repeatedly used for a certain type of characters, we expect it to become a well-recognized language variation. The fictional characters, boku-girls and ore-girls, were evidently constructed through intralingual translanguaging, by manipulating the boundary between gender-sensitive pronouns and shaping their idealized group identity with specific sets of linguistic features.

Whether girls who actually address themselves with boku or ore exist in reality is a next natural question. Miyazaki (2004) studies the use of first-person pronouns by students in a junior high school in Japan and reports that the firstperson pronoun ore was used by a group of female students in the school. This group had "a distinctive subculture and language that both its members and other students considered gehin "vulgar" (Miyazaki, 2004, p. 262). They invented dances to express their disdain for the uniforms that they were required to wear. The students in this group obviously did not behave or speak like typical traditional female students. Their intralingual translanguaging in terms of the choice of gender-sensitive personal-pronoun was their tool to redefine their unique identity: The use of ore helped them shift their identities so they could free themselves from their society's expectation on how girls should behave.

The use of first-person pronouns is even more complex for LGBT people. Abe (2004) conducts research at lesbian bars in Tokyo to examine the relationship between gender-identity and language use. She recognized three types of people at lesbian bars: Transsexuals, lesbians and onabe (literally, "pan"). Transsexuals in this context are female-tomale transsexual/transgender people. Lesbians are women who feel comfortable with their biologically female sex and choose a woman as a partner, but unlike straight women, their female identity is constructed through a relationship with another woman. Onabes are women who love women and choose a woman as a partner, but their social and emotional identity is male. Abe (2004) observed the use of first-person pronouns found in a magazine transcript of a panel discussion among two transsexuals, two lesbians and two onabes. She found that the transsexuals used boku, the lesbians used watashi, and the onabes used jibun, to address themselves, almost uniformly (p. 213). This shows that intralingual translanguaging facilitates the shift of their non-biological master identity.

However, Abe (2004, p. 214) finds that the choice of pronouns also varies depending on the situational context even with the same person. For example, a 20-year-old employee at a lesbian bar was constantly addressing herself using jibun (oneself) when speaking with her female supervisor, her coworkers and customers. She stated that she did not want to sound too feminine by using watashi or atashi, and did not want to sound too masculine by using washi, which is used by her boss. Thus, jibun was the least gender-explicit option for her. However, she suddenly started to use ore, a first-person masculine pronoun, when her female customer telephoned her. This customer of hers caused an enormous problem and pain to her on the previous night at the bar. In this case, the employee's shift from jibun (oneself) to ore (first-person masculine pronoun) was triggered by her emotion: she was angry at her customer for her misbehavior on the previous night. It is possible that this shift occurred because she failed to maintain her gender-neutral stance due to her anger. As a result, her interactional identity as an employee who serves her customer at the lesbian bar was suddenly interrupted and her relational identity as a subordinate to her customer became void.

Abe (2004) reports another case of a change of the first-person pronoun. A lesbian speaker who usually addresses herself with atashi confessed that she uses boku when she makes a false show of power, for example, when she confronts her male boss, who may suspect that she is a lesbian, at work. According to her, this helps her "situate herself at the boss's level" (Abe, 2004, p. 215). The shift from atashi to boku in this case was deliberately made based on her belief that maleness implies power and strength, and facilitated the temporary construction of her new relational identity, where power imbalance between her and her male boss was eliminated and her and her male boss' levels were equalized. This also shows a fluid language use disregarding the boundary between two gendered language varieties in Japanese, a case of intralingual translanguaging, which can effectively and momentarily construct, shift or adjust one's identities.

\section{CONCLUSION}

This paper explored the role of translanguaging (García \& Li, 2014; Li, 2011, 2016, 2018) for constructing a language variety and its associated group identity reflecting the communicative context and the surrounding sociohistorical and socio-political ideologies as well as shaping them depending on the space, time, and purpose of communication. Gender-based language varieties in Japanese were analyzed, both diachronically and synchronically, to reveal how master, interactional, personal and relational identities (Tracy, 2002, Young, 2017) are formed and altered depending on the context of language use. The historical development of women's language and the use of first-person pronouns in multiple context in the current society were analyzed.

Women's language in Japanese was societally constructed rather than resulted from the language users' physiological and psychological nature. It absorbed all in-betweenness in the male-dominant society at a major turning point in the Japanese history, where dual-values were prevailing. This paper has argued that the linguistic features from schoolgirls' language (Inoue, 2002, 2006) and court ladies' language (Endo, 1997, 2008) were deployed for collectively constructing women's languages and its group identity. Importantly, this process was facilitated by both intra- and interlingual translanguaging, showing that the division between named and unnamed languages is irrelevant to translanguaging practice (Li, 2018). 
In addition based on some preceding studies of the use of gender-sensitive first-person pronouns in fictional characters (Nishida, 2011), among junior high school students (Miyazaki, 2004), and at lesbian bars (Abe, 2004), this paper also demonstrated that intralingual translanguaging is sensitive to each communicative context and allows language users to reveal or manipulate their master identity, to conform to or resist social norms, to void or adjust existing interactional and relational identities, and even to create a new personal identity. Translanguaging perspective provides segment-by-segment image of Bakhtinian view of language as emerging from and evolving in the context of language use.

The application of a translanguaging perspective to the study of historical development of languages is extremely useful to see the connection between languages and their surrounding societies as well as the nature of languages and language use.

The current study is based on the data and facts presented by the limited number of preceding studies. Thus, further research is needed to explore the language users' creative and critical mindset that triggers translanguaging practices through a wider variety of primary and secondary data in order to explore language users' intentions and feelings.

\section{ACKNOWLEDGMENTS}

This work was supported in part by a grant from FAHSS at Stony Brook University. The author appreciates two anonymous reviewers for giving helpful comments, criticisms and suggestions.

\section{REFERENCES}

[1] Abe, H. (2004). Lesbian bar talk in Shinjuku, Tokyo. In S. Okamoto \& J. Shibamoto Smith (Eds.), Japanese language, gender, and ideology: Cultural models and real people. New York: Oxford University Press, 205-221.

[2] Baker, C. (2001). Foundations of bilingual education and bilingualism (3rd ed.). Clevedon, UK: Multilingual Matters.

[3] Baker, C. (2003). Biliteracy and transliteracy in Wales: Language planning and the Welsh national curriculum. In N. Hornberger (Ed.), Continua of biliteracy. Clevedon: Multilingual Matters, 71-90.

[4] Blackledge, A. \& A. Creese. (2010). Multilingualism: A critical perspective. London: Continuum.

[5] Bohn, M. \& Y. Matsumoto (2008). Young women in the Meiji period as linguistic trendsetters. Gender and Language 2.1, 5186. doi:10.1558/genl.v2i1.51.

[6] Bucholtz, M. \& K. Hall. (2004). Language and identity. In A. Duranti (ed.), A companion to linguistic anthropology. Malden, MA: Blackwell, 369-394.

[7] Canagarajah, S. (2011). Codemeshing in academic writing: Identifying teachable strategies of translanguaging. The Modern Language Journal 95, 401-417. doi:10.1111/j.1540-4781.2011.01207.x.

[8] Chow, R. (2014). Not like a native speaker: On languaging as a postcolonial experience. New York: Columbia University Press.

[9] Creese, A. \& A. Blackledge. (2010). Translanguaging in the bilingual classroom: A pedagogy for learning and teaching? Modern Language Journal 94.1, 103-115. doi:10.1111/j.1540-4781.2009.00986.x.

[10] Endo, O. (1997). Onna no kotoba no bunka-shi [Cultural history of the women's language]. Tokyo: Gakuyō shobō.

[11] Endo, O. (2008). The role of court lady's language in the historical norm construction of Japanese women's language. Gender and Language 2.1, 9-24. doi:10.1558/genl.v2i1.9.

[12] Fishman, J. A. (1991). Reversing language shift: Theoretical and empirical foundations of assistance to threatened languages. Clevedon: Multilingual Matters.

[13] García, O. (2007). Foreword. In S. Makoni, \& A. Pennycook (Eds.), Disinventing and reconstituting languages. Clevedon: Multilingual matters, $x i-x v$.

[14] García, O. (2009). Bilingual education in the 21st century: A global perspective. Malden, MA: Wiley-Blackwell.

[15] García, O. \& W. Li (2014). Translanguaging: language, bilingualism and education. Houndmills: Palgrave Macmillan.

[16] García, O. \& A. M. Y. Lin. (2016). Translanguaging in bilingual education. In O. García, \& A. M. Y. Lin (Eds.), Bilingual and Multilingual Education. Dordrecht: Springer.

[17] García, O. \& A. M. Y. Lin. (2018). English and multilingualism: A contested history. In P. Seargeant, A. Hewings, S. Pihlaja (Eds.), The Routledge Handbook of English Language Studies. London: Routledge.

[18] Ide, R. \& T. Terada. (1998). The historical origins of Japanese women's speech: From the secluded worlds of "court ladies" and "play ladies." International Journal of Sociology of Language 129, 139-156.

[19] Inoue, M. (2002). Gender, language, and modernity: Toward an effective history of Japanese women's language. American Ethnologist 29.2, 39 -422.

[20] Inoue, M. (2006). Vicarious language: Gender and linguistic modernity in Japan. Berkeley, Calif: University of California Press.

[21] Jørgensen, J. N., M. S. Karrebæk, L. M. Madsen, \& J. S. Møller. (2011). Polylanguaging in superdiversity. Diversities 13.2, 23-37.

[22] Kinsui, S. (2003). Vuācharu nihongo yakuwarigo no nazo [The mystery of virtual Japanese role language]. Tokyo: Iwanami.

[23] Kinsui, S. (2014). "Yakuwarigo" shōjiten [Small dictionary for "role languages"]. Tokyo: Kenkyūsha.

[24] Kosugi, T. (1930 [1903]) Makaze koikaze [Magic Wind, Love Wind]. In Meiji Taisho Bungaku Zenshuu: Kosugi Tengai [The Complete Works of Literature from the Meiji and Taisho Periods: Kosugi Tengai] vol. 16. Tokyo: Shunyōdō, 1-300. (Cited in Bohn \& Matsumoto, 2008).

[25] Lee, T. K. (2015). Translanguaging and visuality: Translingual practices in literary art. Applied Linguistics Review 6.4, 441465. doi:10.1515/applirev-2015-0022.

[26] Levy, I. (2006). Sirens of the western shore: The westernesque femme fatale, translation, and vernacular style in modern Japanese literature. New York: Columbia University Press. 
[27] Levy, I. H. (1981). The ten thousand leaves: A translation of the Man'yōshū, Japan's premier anthology of classical poetry. Princeton, N.J: Princeton University Press.

[28] Lewis, G., B. Jones \& C. Baker. (2012). Translanguaging: Origins and development from school to street and beyond. Educational Research and Evaluation: An International Journal on Theory and Practice 18.7, 641-654. doi:10.1080/13803611.2012.718488.

[29] Li, W. (2011). Moment analysis and translanguaging space: Discursive construction of identities by multilingual Chinese youth in Britain. Journal of Pragmatics 43, 1222-1235. doi:10.1016/j.pragma.2010.07.035.

[30] Li, W. (2016). Epilogue: Multi-competence and the Translanguaging Instinct. In V. Cook \& L. Wei (Eds.), The Cambridge handbook of linguistic multi-competence. Cambridge: Cambridge University Press, 533-543. doi:10.1017/CBO9781107425965.026.

[31] Li, W. (2018). Translanguaging as a practical theory of language. Applied Linguistics 39.1, 9-30.

[32] Lin, A. (2014). Hip-hop heteroglossia as practice, pleasure, and public pedagogy: Translanguaging in the lyrical poetics of " 24 Herbs" in Hong Kong. In A. Blackledge, \& A. Creese (Eds.), Heteroglossia as practice and pedagogy. Heidelberg: Springer, 119-136. doi:10.1007/978-94-007-7856-6_7.

[33] Makoni, S. \& A. Pennycook. (2007). Disinventing and reconstituting languages. Clevedon: Multilingual Matters.

[34] Miyake, K. (1957 [1888]). Yabu no uguisu [Warbler in the grove]. In Meiji shōsetsu shū: Gendai nihon bungaku zenshū [The collection of Meiji novels: The complete works of modern Japanese literature) vol. 83. Tokyo: Chikuma Shobō, 35-53. (Cited in Bohn \& Matsumoto, 2008).

[35] Miyazaki, A. (2004). Japanese junior high school girls' and boys' first-person pronoun use and their social world. In S. Okamoto \& J. Shibamoto Smith (Eds.), Japanese language, gender, and ideology: cultural models and real people. New York: Oxford University Press, 256-274.

[36] Myhill, J. (1999). Identity, territoriality and minority language survival. Journal of Multilingual and Multicultural Development $20.1,34-50$.

[37] Nakamura, C. (2018). How is the Japanese Women's Language used today? manuscript, Stony Brook University.

[38] Nakamura, M. (2008). Masculinity and national language: The silent construction of a dominant language ideology. Gender and Language 2.1, 25-50. doi:10.1558/genl.v2i1.25.

[39] Nakamura, M. (2014). Gender, language and ideology: A genealogy of Japanese women's language. Amsterdam: John Benjamins Publishing Company.

[40] Nishida, T. (2011). "Boku-shoujo" no gengo hyougen: jouyousei no aru zokusei hyougen to yakuwarigo no setten [Linguistics expression of "boku shoujo": The relation between "attributive expression" and role language]. Kounan Women's College Journal 48, 13-22.

[41] Okamoto, S. \& J. S. Shibamoto-Smith. (2016). The social life of the Japanese language: Cultural discourses and situated practice. Cambridge: Cambridge University Press.

[42] Okamoto, S. \& J. S. Smith. (2008). Constructing linguistic femininity in contemporary Japan: Scholarly and popular representations. Gender and Language 2.1, 87-112. doi:10.1558/genl.v2i1.87.

[43] Otheguy, R., O. García \& W. Reid. (2015). Clarifying translanguaging and deconstructing named languages: A perspective from linguistics. Applied Linguistics Review 6, 281-308.

[44] Pavlenko, A. \& A. Blackledge (eds.). (2004). Negotiation of identities in multilingual contexts. Clevedon: Multilingual Matters

[45] Philippi, D. L. (1969). Kojiki. Princeton, NJ: Princeton University Press.

[46] Sato, E. (2017). Translanguaging in translation: Evidence from Japanese mimetics. International Journal of Linguistics and Communication 5.2, 11-26. doi:10.15640/ijlc.v5n1a2.

[47] Sato, E. (2018a). Sociocultural implications of the Japanese multi-scripts: Translanguaging in translation. In H. Pae (ed.), Writing systems, reading processes and cross-linguistic influence: Reflections from the Chinese, Japanese and Korean languages. Amsterdam/Philadelphia: John Benjamins, 313-332. doi:10.1075/bpa.7.15sat.

[48] Sato, E. (2018b). Translanguaging in translation: Manipulation of an intralingual boundary between vocabulary classes, Paper presented at TLANG (Translation and Translanguaging) Conference, Birmingham, U.K.

[49] Sato, E. \& A. Sharma. (2017). Translanguaging in translation: A case study of an English translation of a Hindi novel "Godaan." International Journal of Language and Literature 5.2, 132-145. doi:10.15640/ijll.v5n2a14.

[50] Tracy, K. (2002). Everyday talk: Building and reflecting identities. New York: Guilford.

[51] Young, R. F. (2017). World languages, world Englishes and local identities. World Englishes 36.4, 488-508. doi:10.1111/weng.12249.

Eriko Sato is Assistant Professor of Translation Studies and Japanese Linguistics at Stony Brook University, where she serves as the Director of Asian languages. She authored Contemporary Japanese (Tuttle), Japanese Demystified (Wiley), Complete Japanese Grammar (McGraw-Hill) and many more Japanese textbooks and grammar books. 